\title{
Changes after Enforcement of Supervision Law in China
}

\author{
Jiaming Zhang1, Na Jiang² \\ ${ }^{1}$ Political Science and Law School of Changchun Normal University, Changchun, China \\ ${ }^{2}$ Center of Criminal Law of Beijing Normal University, Beijing, China \\ Email: na.jiang@bnu.edu.cn
}

How to cite this paper: Zhang, J. M., \& Jiang, N. (2019). Changes after Enforcement of Supervision Law in China. Chinese Studies, 8, 222-229.

https://doi.org/10.4236/chnstd.2019.84018

Received: October 23, 2019

Accepted: November 26, 2019

Published: November 29, 2019

Copyright (c) 2019 by author(s) and Scientific Research Publishing Inc. This work is licensed under the Creative Commons Attribution International License (CC BY 4.0).

http://creativecommons.org/licenses/by/4.0/

\begin{abstract}
The Supervision Law of PRC has enforced in 2018, which led to a series of great changes in China. The new anti-corruption system has been formed in China, as supervisory commissions at various levels with broad power to curb corruption crimes. The study of supervisory commission provides two original approaches. It provides new insights and details into the new supervisory institutions in China. On the other hand, the reasons behind the authorities have been revealed. And the key factors in supervising corruption can be summarized, which are critical to anti-corruption. No matter commissions for discipline inspection or people's procuratorate occurred lots of changes. While, the alterations are worth researching and rethinking to rise the efficiency of combating corruption. This article attempts to analyze the changes to seek for the path of supervising corruption by current laws.
\end{abstract}

\section{Keywords}

National Supervisory Commission, China, Changes, Enforcement of Supervision Law

\section{Introduction}

Since reform and opening up in 1978, a series of system reform is performing to combat corruption in China. A great amount of policies are implementing to obtain "tigers as well as swallows" (老虎苍蝇). National Supervisory Commission (NSC) is one production of reform (BBC Monitoring Asia Pacific, 2018).

Moreover, it is a crucial step to enforce the Supervision Law in 2018, which has far-reaching influence in supervisory system in China. Both commissions for discipline inspection and supervisory commissions have their own name; the supervisory commission has co-located with commissions for discipline inspec- 
tion. Actually, they are “two brands of an institution” (一个机构两块牌子). Finally, the new anti-corruption system consists of commissions for discipline inspection, supervisory commissions and people's procuratorates.

The purpose of this article is to pursue the effective way to combat corruption and achieve balance between broad power and civilian's rights. Therefore, the article focuses on NSC, which is a brand-new watchdog in China, specifically, analyzing the powers, branches, operation of National Supervisory Commission.

\section{Literature Review}

The results of the global investigation show that corruption is one of the serious issues (Graycar \& Masters, 2018; Hobbs \& Williams, 2017; Stone, 2015). Some scholars argue that there are mainly five reasons for corruption in developing countries such as China, including human greed, institutional omissions, economic transition, the weakness of the civil society (Tang, Ding, \& Xu, 2018). Some believe that corruption is account for political power and its abuse in China (Smart \& Hsu, 2008).

Though corruption is not a new criminal crime, there are diversity fierce debates (Jiang, Lo, \& Li, 2013; Tang, Ding, \& Xu, 2018; Pieth, 2018). There is not a uniform definition of corruption, ${ }^{1}$ so do the anti-corruption bodies. Countries usually establish supervisory agencies according to their different cultures and facts (Heimann, 2018).

With the reform and opening up, the economy of China is prosperity and development. However, corruption conditions are worrying (Supreme People's Court work report 2014-2018, 2019). According to Transparent International's Corruption Perceptions Index (CPI), the score of China is only 39 in 2018 (Transparency International, 2018), which has declined to compare with the score of 2017.

Current literature on anti-corruption focuses on the measures and anti-corruption system. First of all, there are diversity ideas about reducing corruption. One of the ideas called "social anti- corruption", which means "develop a social anti-corruption system and cultivating a culture of integrity, we should improve social participation, strengthen social supervision, promote anti-corruption education, and improve legal development, ultimately making officials unwilling to corrupt" (Feng, 2018). Some researches explain the relationship between organized crime, corruption and extra-legal protection, which figures the Guanxi is a critical element of corruption in China (Wang, 2017). Furthermore, the factors involved the corruption also are the main topic of the research. Some scholars claim that "human greed, economic transition, institutional omissions, a weak civil society, and social and cultural traditions are found to be the main causes of corruption in China" (Tang, Ding, \& Xu, 2018). Last but not least, recent literature studies the anti-corruption campaigns in China and argues that China's previous dual-track anti-corruption system has ${ }^{1}$ It is a broader conception in China, not only refers to "the abuse of public power for personal interests", but also braces the behavior against some rules of CCP's discipline. 
changed by the establishment of the new anti-corruption agency-supervisory commission (Deng, 2018). The new anti-corruption authority of China which has broadly supervisory territory and strong powers was established formally in 2018. The new anti-corruption system, especially, the supervisory commission still relies upon powerful political leadership and becomes the unique strongest agency in anti-corruption system. The new supervisory authority was formed universally after implemented in three experimental locations for a fixed period, which means that the supervisory commission was established in several provinces $^{2}$ of China firstly in 2016 (the NPCSC Decision Approving the Establishment of the SC System in Beijing, Meng, 2016). Summarizing the features of the supervisory system reform (Chen \& Shao, 2017), debating the scope of the supervisory commission's powers (Smith, 2017).

The above research helps us to understand the conception of corruption in China, the system of the supervision, the background of establishing the new anti-corruption, the branches of the supervisory commission and their powers even the relationship between National Supervisory commission and commission for discipline inspection. Since the existing time of the NSC is less than two years, it is difficult to explore it deeply and adequately. Therefore, it reminds us to pay more attention to research on implementing of NSC, specifically, the operation of the new anti-corruption system, the balance between the powers and the human rights, the main effective factors in countering corruption.

\section{Discussion}

\subsection{Changes of Supervisory Frame by Supervision Law}

Before establishing NSC, the anti-corruption system was dual-track ${ }^{3}$ (Deng, 2018). However, the economy is huge degree of growth, social development in the speeding, it is hardly to supervise corruption successfully in dual-track mode, which means that the cases relate to members of CCP are investigated by commissions for discipline inspection, if the respondent probable commit crimes, the case would be transferred to people's procuratorate. Under judicial system, cases of corruption are investigated and prosecuted by people's procuratorate. However, it is not an efficient and sufficient supervision, since the local leaders can intervene in investigating even judging cases (Li, Gong, \& Xiao, 2016; China Youth Daily, 2016). There are two reasons for the situation. Firstly, both people's procuratorate and commissions for discipline inspection were controlled by local finance before judicial system reform. It is not accident that a ${ }^{2}$ There were three pilot areas: Beijing, Shanxi province and Zhejiang province, they were chosen in 2016.

${ }^{3}$ It was a supervisory mode that contains two tracks, one refers to CPC's disciplinary affairs -investigate by commission for discipline inspection (CCDI). The other is the judicial system which is responsible to investigate and prosecute cases by prosecutors. The boundary between them is whether the subject of the investigation or the suspect is member of Communist Party of China and which the proceeding in. If the investigator is not a member of Communist Party of China or he/she is going to be transferred to prosecution, the watchdog definitely is the People's Procuratorate. 
case is surrendered by local government (Chen, 2017). Secondly, both people's procuratorate and commissions for discipline inspection were connected closely with local leaders before judicial system reform. The leaders of people's procuratorate and were subordinate staff in local structure, it was hard to investigate some higher leaders, and moreover, it was easy to be interfered by local party leaders. The former supervisory system is mainly constitutive of commissions for discipline inspection and people's procuratorates.

By contrast, the new supervisory body contains discipline inspection, supervisory commissions and people's procuratorates. Due to judicial reform and new supervisory system, the judicial authority is vertical leadership which guarantees the independent exercise of powers. No matter finance or leaders are barely effected by local government. The new supervisory frame means that most of corruption cases are investigated by supervisory commissions and the anti-corruption force is more concentrated by the Party. On the other hand, the progress of combating corruption is more effective due to strong supervisory power. For instance, case of Jinqi $\mathrm{Yao}^{4}$ as a typical succeeds extradition to certify the high effect of the new supervisory commission (Beijing Daily, 2019).

\subsection{Changes of Investigative Power and Objects by Supervision Law}

Before, the objects of supervisory organ were state administrative organs, civil servants and the staff who appointed by state administrative organs. However, now it watchdogs generalized government instead of narrow government. For instance, organs of democratic parties are also supervised now. The supervisory commission can watchdog every person or institution even state-owned enterprise. On one hand, it expands the objects of watchdogs and combines the supervisory resources. Now, "national supervisory system is organic unify of inner-party supervision and state organ supervision, party discipline inspection and national supervision." Village cadres who are non-party members cannot be supervised unless their behaviour against criminal law before 2018. Since " $S u$ pervision law of the $P R C$ " came into force, the non-party members of village cadres are also supervised. However, we can abstract a key word "party leadership" which is more emphasized anti-corruption by politics rather than laws (Deng, 2018).

Supervisory commissions is characterised of possessing broad investigative power. The supervisory commission shall "perform the duties of supervision, investigation and disposition". Specifically, one supervisory commission uses supervision can inquiry, interrogation, have a talk, collect and retrieve evidence, frozen moveable property.

There are three limit terms when a supervisory commission makes inquiries about and freeze the moveable property.

${ }^{4}$ Yao who was charged with taking bribes had fled 13 years. It is the first extradite case of supervisory commission, only takes 44 days to extradite Yao.

${ }^{5}$ It is called "liuzhi" in Chinese, a measure is taken to deprive personal liberty. 
1) Cases must be relevant to "corruption, bribery, neglect of duty, malfeasance in office, or any other serious duty-related violation or duty-related crime". It means not every case can be taken these measures.

2) The subject of property ought to own by the suspected the entity or individual involved in the case, the property including savings, remittances, bonds, stocks and fund shares. They cannot make inquiries about and freeze the moveable property that does not involve the investigated cases.

3) The freezing should be removed within three days after the facts are ascertained and the property shall be returned if the frozen property is found to be not relevant to the case. It is a rescue rule for the mis-frozen property. ${ }^{6}$

If an organ collects, seizes or impounds property and documents, special accounts and places should be established, and special persons should be designated to appropriately take them into custody, accounts should be verified on a periodical basis. "The articles of which the value is uncertain shall be subject to identification in a timely manner, and be specially sealed for preservation."7

There are strict applied prerequisites to take technical investigation measures.

1) Conducting investigation of any suspected major duty-related crime such as corruption and bribery;

2) Perform strict approval formalities;

3) Clearly state the types of technical investigation measures and their targets;

4) Be valid for three months as of the date of issuance.

If it is still necessary to take technical investigation measures with respect to a complicated or difficult case after the expiration of the period of validity, the period of validity may be extended upon approval for not more than three months each time. If it is unnecessary to continue taking technical investigation measures, such measures shall be removed in a timely manner. ${ }^{8}$

Though the extended period is limited, it does not limit the times of extending technical investigation measures. In some cases, the measures can be taken as long as the supervisory commission needs.

If the person under investigation and relevant persons from escaping outside the territory of China, she or he will be confined in China. "In order to prevent the person under investigation and relevant persons from escaping outside the territory of China, the supervisory organ may, with the approval of the supervisory organ at or above the provincial level, take measures to restrict the person under investigation and related personnel from leaving the territory." Such measures are taken by public security organ.

Detention is different from the conception in West. It is a measure that created by China. There are restrictions on the use of detention.

1) Applicable procedure

Only collective research of leaders of the supervisory authority owns decision. If a supervisory organ at or below the level of a districted city adopts detention ${ }^{6}$ Supervision Law of the People's Republic of China 2018 ss23. 
measure, it shall be reported to the supervisory organ at the immediately higher level for approval. A provincial supervisory organ "decides to take the detention measure shall report it to the National Supervisory Commission for recordation."

2) Detention period

Detention should within three months. "Under particular circumstances, the supervisory organ may extend the detention once for not more than three months. If a supervisory organ at or below the provincial level takes the detention measure, the extension shall be reported to the supervisory organ at the immediately higher level for approval. "Therefore, the longest detention period should not longer than six months." It is a protection to the respondents that are taken detention.

3) Notice

"The entity where the detained person works and his or her family member shall be notified within 24 hours after the detention measure is taken against the person under investigation." If evidence may be destroyed or forged, the testimony of a witness may be interfered with, a false confession may be made in collusion, or the investigation may otherwise be affected, the supervisory organ need not notify the detained person's work unit and his or her family. "After the circumstance which affects investigation disappears, the entity where the detained person works and his or her family member shall be notified immediately." 10

4) Guarantee

By the law, "the supervisory organ shall guarantee the food, drink, rest and security of the detained person, and provide medical services. Interrogation time and length shall be reasonably arranged for the interrogation of the detained person, and interrogation records shall be signed by the interrogated person after reading." ${ }^{10}$ But there is not explicitly stipulated what "reasonably" is. It is hard to confine the behaviour of supervisory staff and their responsibilities.

\section{Conclusion}

It has demonstrated that a new anti-corruption body had been established with broad power since Supervision Law enforced. New supervisory system is more efficient than before but also facing challenges. Nevertheless, it is a new sharp sword to combat corruption.

\section{Project Research}

This research is the outcome of project Research on the national anti-corruption legislation with Chinese characteristics (Center for Public Integrity of Changchun Normal University), as well as a part of project funded by the Ministry of Justice, P.R.C. (14SFB30018; “sixing cuo an bijiao yanjiu”).

\footnotetext{
${ }^{9}$ Supervision Law of the People's Republic of China 2018 ss43.

${ }^{10}$ Supervision Law of the People's Republic of China 2018 ss 44.
} 


\section{Conflicts of Interest}

The authors declare no conflicts of interest regarding the publication of this paper.

\section{References}

Hobbs, H., \& Williams, G. (2017). The Case for a National Whole-of-Government Anti-Corruption Body. Alternative Law Journal, 3, 178-183. https://doi.org/10.1177/1037969X17730190

Deng, J. T. (2018). The National Supervision Commission: A New Anti-Corruption Model in China. International Journal of Law, Crime and Justice, 52, 58-73. https://doi.org/10.1016/j.ijlcj.2017.09.005

Stone, B. (2015). Accountability and the Design of an Anticorruption Agency in a Parliamentary Democracy. Policy Studies, 2, 1-19. https://doi.org/10.1080/01442872.2014.1000844

Jiang, G., Lo, T., \& Li, C. (2013). Youths' Views on Corruption Control in China: Politics and Social Censure. International Journal of Offender Therapy and Comparative Criminology, 12, 1498-1521. https://doi.org/10.1177/0306624X12457351

Li, H., Gong, T., \& Xiao, H. (2016). The Perception of Anti-Corruption Efficacy in China: An Empirical Analysis. Social Indicators Research, 3, 885-903. https://doi.org/10.1007/s11205-015-0859-Z

Feng, Y. H. (2018). Social Anti-Corruption: A New Idea of Anti-Corruption Governance in China. Advances in Social Science, Education and Humanities Research, 266, 467-471. https://doi.org/10.2991/hssmee-18.2018.78

Chen, G. Z. (2017). Several Views on the Reform of China's Supervisory System. Global Law Review, 2, 115-117.

Chen, G. Z., \& Shao, J. (2017). Reflections on Some Issues in the Reform of China's Supervisory System. China Law, 4, 23-36.

Graycar, A., \& Masters, A. B. (2018). Preventing Malfeasance in Low Corruption Environments: Twenty Public Administration Responses. Journal of Financial Crime, 25, 170-186. https://doi.org/10.1108/JFC-04-2017-0026

Pieth, M. (2018). What Is Corruption. In F. Heimann, \& M. Pieth (Eds.), Confronting Corruption (pp. 29-45). New York: Oxford University Press. https://doi.org/10.1093/oso/9780190458331.003.0004

Tang, N., Ding, Z., \& Xu, Y. N. (2018). Corruption and Anti-Corruption Research in China: A Critical Review of Chinese Top Journal Publications (1989-2017). Chinese Public Administration Review, 9, 79-98. https://doi.org/10.22140/cpar.v9i2.167

Wang, P. (2017). China's War against Mafias. In P. Wang (Ed.), The Chinese Mafia: Organized Crime, Corruption, and Extra-Legal Protection (pp. 185-196). Oxford: Oxford University Press. https://doi.org/10.1093/acprof:oso/9780198758402.003.0008

Heimann, F. (2018). Different Strategies for Different Countries. In F. Heimann, \& M. Pieth (Eds.), Confronting Corruption: Past Concerns, Present Challenges, and Future Strategies (pp. 255-267). New York: Oxford University Press.

Smart, A., \& Hsu, C. L. (2008). Corruption or Social Capital? Tact and the Performance of Guanxi in Market Socialist China. In M. Nuijten, \& G. Anders (Eds.), Corruption and the Secret of Law: A Legal Anthropological Perspective Policy (pp. 167-189). London: Ashgate Publishing Ltd. https://doi.org/10.4324/9781315259208-8

Transparency International (2018) Corruption Perceptions Index. https://www.transparency.org/cpi2018 
Meng, Y. X. (2016). The NPCSC's Decision. http://news.sohu.com/20161226/n476906729.shtml

Smith, T. (2017). Power Surge: China's New National Supervisory Commission. In Jane Golley, Linda Jaivin, Paul J. Farrelly and Sharon Strange (Eds.), China Story Yearbook 2018: Power, (pp. 32-35). Canberra: Australian National University Press.

BBC Monitoring Asia Pacific (2018). Director of China's New Anti-Corruption Body Elected. http://search.proquest.com/docview/2014659385

China Youth Daily (2016). Judicial Intervention Definitely Is Not a Skill of Leadership. http://www.xinhuanet.com/politics/2016-02/16/c_128722945.htm

Beijing Daily (2019). The National Supervisory Commission Did These Issues in the First Anniversary of the Establishment. https://baijiahao.baidu.com/s?id=1628761705695287129\&wfr=spider\&for $=\mathrm{pc}$

(2019). Supreme People's Court Work Report 2014-2018.

http://english.court.gov.cn/reports.html 